\title{
The Impact of Financial, Non-Financial, and Corporate Governance Attributes on The Practice of Global Reporting Initiative (GRI) Based Environmental Disclosure*
}

\author{
Frendy \\ Faculty of Economics and Business, Universitas Gadjah Mada \\ Indra Wijaya Kusuma \\ Faculty of Economics and Business, Universitas Gadjah Mada
}

\begin{abstract}
Business entities are able to exert their influence on particular stakeholders for the benefit of their interest by managing the information they disseminate to the public, particularly if there is no regulation on such issue in place. Accordingly, the extent of accounting information disclosed to the public, specifically voluntary environmental information, is determined by the internal characteristics of the business entities. The objective of this research is to test the financial, non-financial, and corporate governance attributes of Indonesian public companies which contribute to the extent of environmental information disclosure in Indonesia.

This research measured the extent of Indonesian public companies' environmental disclosure using Environmental Disclosure Index (EDI) as a dependent variable. The index is developed from the parameters under environmental protocols of the Global Reporting Initiative (GRI) G3 framework. Samples of 35 Indonesian public companies are purposively chosen for each of the year from 2005-2008 to form a total of 140 observations.

The testing results conclude that size of company, economic performance, and industry sensitivity positively affect environmental disclosure. This research is limited by an assumption that Indonesian public companies employ annual report as the primary means to publicize financial and non-financial information to public.
\end{abstract}

Abstrak: Entitas bisnis dapat menggunakan pengaruh mereka pada pihak tertentu untuk kepentingan mereka dengan mengelola informasi yang mereka sebar-luaskan kepada publik, terutama jika tidak ada peraturan mengenai masalah tersebut. Dengan demikian, sejauh mana informasi akuntansi diungkapkan kepada lingkungan masyarakat, khususnya informasi lingkungan sukarela, ditentukan oleh karakteristik internal dari badan usaha. Tujuan dari penelitian ini adalah untuk menguji atribut tata kelola keuangan, nonkeuangan, dan perusahaan perusahaan publik Indonesia yang berkontribusi pada tingkat pengungkapan informasi lingkungan di Indonesia.

* This paper has been presented in the $14^{\text {th }}$ National Accounting Symposium at Syiah Kuala University, Banda Aceh (21st - 22nd July 2011). The authors would like to thank the anonymous reviewers and participants of the symposium for their helpful comments.

Corresponding authors. E-mail: indra.kusuma@gadjahmada.edu, and frendy.lee@gmail.com

ISSN: $1141-1128$

http://www.gamaijb.mmugm.ac.id/ 
Penelitian ini mengukur tingkat pengungkapan lingkungan perusahaan publik menggunakan Environmental Disclosure Index (EDI) sebagai variabel dependen. Indeks ini dikembangkan dari parameter di bawah protokol lingkungan dari kerangka Global Reporting Initiative (GRI) G3. Contoh dari 35 perusahaan publik terpilih di Indonesia untuk setiap tahun dari 2005-2008 untuk membentuk total 140 observasi.

Hasil pengujian menyimpulkan bahwa ukuran perusahaan, kinerja ekonomi, industri dan sensitivitas positif mempengaruhi pengungkapan lingkungan. Penelitian ini dibatasi oleh asumsi bahwa perusahaan-perusahaan publik Indonesia menggunakan laporan tahunan sebagai sarana utama untuk mempublikasikan informasi keuangan dan non-keuangan kepada publik.

Keywords: annual report; corporate governance; environmental disclosure; financial; non-financial; global reporting initiative; Indonesian public companies 


\section{Introduction}

Accountability is defined as the responsibility of management to report the achievement of cozmpany's objectives for the utilization of company's resources in an effective and efficient way (Ijiri 1983). One approach to improve the accountability of financial information is the inclusion of social and environment elements into the practice of financial accounting disclosure (Gray et al. 1996).

In recent years, public companies worldwide have increasingly associated themselves as socially and environmentally sustainable entities, as half of Global Fortune 250 was both registered in the stock market and socially responsible indices, such as FTSE4GOOD or Dow Jones Sustainability Index (KPMG 2008). In order to further encourage the inclusion of social and environmental elements in the presentation of accounting information, the preparer and user of financial reports will need to have better understanding of the management motivation to disclose non-financial information in the annual report and its relationship with the internal characteristics of the company itself.

The financial information disclosed to the public, which is presented in the annual financial report, has inherent limitations regarding the types of information that can be communicated. For example, environmental issue has been regarded as an 'externality' which is irrelevant in the financial report. Such notion exists since it is difficult; to quantify all social and environmental consequences resulted from the operational activities of the company into monetary values. However, companies can reap the reward for disclosing the above mentioned non-financial information, as shown in the research by Cohen and
Fenn (1997), who demonstrated positive correlation between the investments of environmentally friendly technology and the performance of the company's stock. Therefore, this research is concerned in investigating the influence of various dimensions of Indonesian public companies on the degree of environmental sensitive information released to public.

In the context of Indonesia, the Indonesian Institute of Accountants (IAI) has not published any Statement of Financial Accounting Standards for publicly traded companies which mandated public companies to disclose information concerning the impact of their business operation to the environment in the financial report. Moreover, the Capital Market Supervisory Agency (Bapepam) did not require the listed companies in Indonesia Stock Exchange (IDX) to provide any environment related information to the investor. Consequently, the practice of disclosing environment related information in the financial report or annual report for public companies in Indonesia is performed voluntarily (Nurhayati et al. 2006). In order to measure the degree of environmentally sensitive information disclosed by the Indonesian public companies, this research utilizes Environmental Disclosure Index (EDI) that is developed from the environmental protocol section of the GRI (Global Reporting Sustainability) G3 framework.

The purpose of this research is to assess which financial, non-financial, and corporate governance variables of Indonesian public companies that influence the extent of environmental information disclosure in Indonesia. The research comes into a conclusion that size of company, economic performance, and industry sensitivity show considerable and positive associations with the 
extent of environmental disclosure. However; financial leverage, business complexity, and stock-block holders exhibit substantial inverse relationships with the observed variable.

\section{Literature Review and Hypotheses Development}

Stakeholders are defined as all human agents who can affect or be affected by the activity of an entity (Gray et al. 1996). This definition implies that the entity and its environment form a complex system which can influence each other. In relevance with the practice non-financial disclosure, stakeholder theory describes that the extent of social information voluntarily disclosed by an entity can be utilized to identify the principal stakeholder for the entity as being the subject for being influenced by the entity (Gray et al. 1996). In other words, the act of an organization to disclose information is seen as a form of 'proactive' action by the entity in managing the relationship with the intended stakeholders.

Environmental disclosure, as a subset of social disclosure, plays a significant part in influencing the decisions of investors. This conclusion is obtained by Spicer (1978), whose research confirmed that there is a significant relationship between the value of investment (economy and financial indicator from the investment such as: profitability, the size of company, systematic and total risk, and price earnings ratio) and the environmental management performance of the company. In addition, research done by Cohen and Fenn (1997) conclude that companies with additional investment in environmentally friendly technology exhibits positive and neutral stock return performance.
The expanded research done by Shane and Spicer (1983) indicate that the movement of stock price is consistent with the change of investor perception after the information concerning the environmental performance of the company is released to the market. Thus, this research postulates that the effort to disclose environmental information represent an attempt by management to manage the stakeholders' expectation as affirmed by the stakeholder theory.

Statement of Financial Accounting Standards (SFAS) No. 1 on Presentation of Financial Report issued by the Indonesian Institute of Accountants (IAI) does not mandate public companies in Indonesia to disclose environmental information. The pronouncement allowed the companies to choose whether or not to disclose such information based on their judgment. As the nature of environmental disclosure practice in Indonesia is voluntarily based, the stakeholder theory is appropriate in describing the motivation and driving force behind the decision of Indonesian public listed companies to disclose such information. This is regarded as one of the evidence in which the entity can proactively assert its influence to the intended stakeholders. Business entities are therefore able to exercise their control on certain stakeholders for the benefit of their interest by overseeing the information they disseminate to public, as there is no regulation in place to standardize their activities in disclosing environmental information. Accordingly, the extent of accounting information disclosed to public, specifically voluntary environmental information, is determined by the internal characteristics of the business entities.

This research utilizes GRI (Global Reporting Sustainability) framework as the ba- 
sis to measure the degree of environmental information disclosed by public companies in Indonesia. The GRI framework is a voluntary based international sustainability reporting framework developed by a large multistakeholder network of thousands of experts and hundreds of organizations (GRI 2009). Based on the GRI G3 framework of the environment protocol, the Environmental Disclosure Index (EDI) is developed to measure the extent of environmental information disclosure released by public companies.

Previous research which investigated the relationship between the characteristics of public companies with the extent of disclosures reveals that the level of social disclosure of sampled public companies in Britain is positively correlated with the level of the companies' activity (Brammer and Pavelin 2004). Research done in developing countries has led to various conclusions. Cahaya et al. (2008) infer that company size and the extent of international operation are significant predictors for social disclosure. While Nurhayati et al. (2006) conclude that the size of company and the industry type of the entity have positive and significant relationships with the extent of environmental disclosure.

\section{Company Size}

Stakeholder theory asserts that large companies are inclined to disclose more information in order to attract more resources from the capital market (Nurhayati et al. 2006). In its relation with political cost, the company size is very influential in determining the size of political cost which has to be paid out by the companies (Watts and Zimmerman 1978). In addition, they argue that the disclosure of non-financial information is considered more effective compared to the disclosure of financial information in affecting the political cost. Large companies will increase the level of voluntarily information disclosure in order to avert excessive government scrutiny.

Previous research concludes the existence of a positive relationship between the size of the company with the extent of social and environmental disclosure (Spicer 1978; Cooke 1989; Meek et al. 1995; Brammer and Pavelin 2004; Nurhayati et al. 2006; Cahaya et al. 2008; Gurdip and Joshi 2009). Accordingly, this study proposes the following hypothesis:

$H_{1}$ : There is a positive association between company size and the extent of GRI based environmental disclosure in Indonesian publicly listed companies' annual reports.

\section{Financial Leverage}

Cornell and Shapiro (1987) argue that the financing policy of corporate (the extent of leverage) is influenced by non-investing and investing shareholders in its relation with the explicit and implicit claims from the management. Explicit claims from the management in the form of financial disclosure are affected by capital investors and creditors. The accounting information disclosure can increase the value of such claims by the management (Watts and Zimmerman 1990).

Results of the research on the association between financial leverage and the extent of disclosure show negative and significant relationships (Meek et al. 1995). Different findings are obtained by Craig and Diga (1998), who argue that there is no significant relationship between leverage and the extent of disclosure. Accordingly, this study proposes the following hypothesis:

$H_{2}$ : There is a negative association between financial leverage and the extent of GRI based environmental disclosure in Indonesian publicly listed companies' annual reports. 


\section{Economic Performance}

Companies with more than average economic performance (profitability) have more incentives to differentiate themselves with companies with lower profitability, with the intention to access lower cost capital (Meek et al. 1995). One way in which the differentiation can be achieved is by disclosing more information voluntarily (Foster 1986). Singhvi and Desai (1971) who examined the quality of financial information disclosure and Roberts (1992) who analyzed the determinant of corporate social responsibility information disclosure conclude that profitability has a positive and significant relationship with the level of disclosure.

Accordingly, this study proposes the following hypothesis:

$H_{3}$ : There is a positive association between economic performance and the extent of GRI based environmental disclosure in Indonesian publicly listed companies' annual reports.

\section{Business Complexity}

The increase of business complexity requires the management of business entity to establish a sophisticated and efficient information system to gather information needed for the purpose of decision making (Cooke 1989). In line with the growing business complexity, the number of stakeholders (suppliers, customers, analysts, and the public) linked with the business will increase as well. This research defines the complexity of business as the existence of subsidiary within the structure of the business entity (Cahaya et al. 2008).

A company with subsidiary tends to have a more sophisticated and efficient business information system to support their business operation as well as the increased demand of information from the stakeholders.
This condition may encourage the company to voluntarily disclose more information. However, the increased complexity also allows the company to engage in various environmentally sensitive matters indirectly with the use of the subsidiary. Previous research shows an insignificant relationship between the business complexities with the extent of financial report disclosure (Cooke 1989; Haniffa and Cooke 2000).

Accordingly, this study proposes the following hypothesis:

$H_{4}$ :There is a negative association between business complexity and the extent of GRI based environmental disclosure in Indonesian publicly listed companies' annual reports.

\section{Extent of International Operation}

The expansion of business operation into international market will bring increased interest from foreign stakeholders. As a result the demand for more diverse information will induce the company to disclose more information (Meek et al. 1995). Research done by Zarzeski (1996) concludes that companies with higher international sales tend to disclose more information.

Accordingly, this study proposes the following hypothesis:

$H_{5}$ :There is a positive association between the extent of international operation and the extent of GRI based environmental disclosure in Indonesian publicly listed companies' annual reports.

\section{Industry Sensitivity}

Companies operating in environmentally sensitive sectors such as forestry and mining are facing more scrutiny and pressure from interested stakeholders due to the di- 
rect impact of their business operations to the environment. Therefore, the type of industry in which the company operates significantly affects the extent of company's voluntarily disclosure (Meek et al. 1995). For the purpose of this research, nine categories of JASICA (Jakarta Industrial Classification) are classified into two groups: environmentally insensitive industries (Property and Real Estate, Infrastructure, Finance, Trade, Services and Investment industries) and environmentally sensitive industries (Agriculture, Mining, Chemical, Consumer Goods and Miscellaneous industries).

A number of researchers who investigate the influence of industry sector to the extent of financial report disclosure exhibit significant relationships (Craig and Diga 1998; Nurhayati et al. 2006; Gurdip and Joshi 2009).

Accordingly, this study proposes the following hypothesis:

$H_{6}$ :There is a positive association between industry sensitivity and the extent of GRI based environmental disclosure in Indonesian publicly listed companies' annual reports.

\section{Stock Block-Holder Structure}

Stock block-holder is defined as the percentage of common stock owned by the majority stockholder, which is used to measure the power of majority stockholders in the company's equity structure (Nurhayati et al. 2006). The management of company in which the stockholder equity is possessed by diversified and more widely dispersed owners will have greater incentive to voluntarily disclose information (McKinnon and Dalimunthe 1993).

Schadewitz and Blevins (1998) demonstrate the inverse relationship between the size institutional investor stock ownership and the extent of interim disclosure. However, Nurhayati et al. (2006) did not find significant relationship between the sizes of stock block-holders with the level of environmental disclosure. Accordingly, this study proposes the following hypothesis:

$H_{7}$ : There is a negative association between stock block-holder structure and the extent of GRI based environmental disclosure in Indonesian publicly listed companies' annual reports.

\section{Board of Commissioners' Structure}

Board of Commissioners' structure in this research is defined as the proportion of independent (non-executive) commissioners from the total number of commissioners (Nurhayati et al. 2006). The argument that the existence of independent commissioners can increase the extent of voluntarily disclosure is based on agency and resource dependency theory, in which independent commissioners have more power to drive the management to disclose more voluntary information compared to non-independent commissioners (Haniffa and Cooke 2000).

Previous research which investigated the relationship between the proportion of independent commissioners with the extent of financial disclosure, exhibit a positive and significant relationship (Chen and Jaggi 2000; Haniffa and Cooke 2000). A different conclusion obtained by Nurhayati et al. (2006) shows an insignificant relationship between the Board of Commissioners' structures with the extent of environmental disclosure. Accordingly, this study proposes the following hypothesis:

$H_{8}$ : There is a positive association between the Board

of Commissioners' structure and the extent of GRI based environmental disclosure in Indonesian publicly listed companies' annual reports. 


\section{Methodology}

This research utilized the annual report of all publicly listed companies in Indonesia Stock Exchange (IDX) for the period of 20052008. The sampling method used is purposive sampling, in which the samples had to be listed in IDX since 2005 and the annual reports had to be published continuously for the period of observation. In addition to published annual reports, this research also considers the information from sustainability reports published separately from the annual reports to measure the Environmental Disclosure Index (EDI). Data panel model which consists of constant cross-sectional units observed for a specific period of time is applied in this research (Gujarati and Porter 2009).

The Environmental Disclosure Index used in this research is based on the Global Reporting Initiative (GRI) G3 environment performance indicators. The EDI score is unweighted to maintain objective and consistent results across samples. The use of an unweighted index is more suitable in the context of disclosure practice in developing countries considering the generally lower quality and quantity of information disclosed (Nurhayati et al. 2006) and distinct social, economic, and political conditions compared to developed economies (Cahaya et al. 2008).

Dichotomous procedure is implemented to measure the total disclosure score for each company's sample, in which disclosed EDI attribute is rated with one (1) point and undisclosed EDI attribute is rated with zero (0) point. The Total Environmental Disclosure (TED) score for each sample is measured as follows (Cooke 1989):

$$
T E D_{i}=\sum_{i=1}^{m} d_{i}
$$

where,

$\mathrm{d}=1$ if EDI disclosure attribute is disclosed $\mathrm{d}=0$ if EDI disclosure attribute is undisclosed, where $\mathrm{m} \leq \mathrm{n}$ (discussed below).

The Maximum Environmental Disclosure (MED) score for each sample is then computed by comparing the TED score with the expected maximum environmental score to be disclosed by considering the industry sector background of each sample, whether the industry is environmentally sensitive or not. This treatment is done to prevent the company for being penalized for irrelevant environmental disclosure attributes not relevant to the industry sector (Cooke 1989). Accordingly, the Maximum Environmental Disclosure (MED) score for each sample is measured as follows:

$$
M E D_{i}=\sum_{i=1}^{n} d_{i}
$$

where,

$d=$ expected EDI disclosure attributes to be disclosed;

$n=$ the maximum number of EDI disclosure attributes that the company expects to disclose, where $n=9$ for environmentally insensitive industry sector (see Appendix 1) and $n=13$ for environmentally sensitive industry sectors (see Appendix 2).

The Environmental Disclosure Index (EDI) score which measures the extent of relative disclosure for each sample is obtained as follows (Cooke 1989): 
Table 1. Independent Variables Measurement Method

\begin{tabular}{|c|c|c|c|}
\hline No. & Independent Variables & Measurement Method & Scale \\
\hline 1. & Company size (LAST) & $\ln$ (Total Assets) & Ratio \\
\hline 2. & Financial leverage (LEV) & Leverage (Total Liabilities / Total Assets) & Ratio \\
\hline 3. & Economic performance (ROA) & Return on Assets & Ratio \\
\hline 4. & Business complexity (SUB) & $\begin{array}{l}0=\text { No subsidiary } \\
1=\text { Subsidiary exists }\end{array}$ & Dummy \\
\hline 5. & Extent of international operation (INT) & $\begin{aligned} 0= & \text { No international sales, subsidiary or branch } \\
1= & \text { International sales, subsidiary or } \\
& \text { branch exists }\end{aligned}$ & Dummy \\
\hline 6. & Industry sensitivity (SEN) & $\begin{aligned} 0= & \text { Environmentally insensitive } \\
& \text { industry sector } \\
1= & \text { Environmentally sensitive industry sector }\end{aligned}$ & Dummy \\
\hline 7. & Stock block-holder structure (SHM) & $\begin{array}{l}\text { Percentage of stocks owned by the majority } \\
\text { stockholders }\end{array}$ & Ratio \\
\hline 8. & Board of commissioners structure (KOM) & $\begin{array}{l}\text { Percentage of independent commissioners } \\
\text { in board of commissioners }\end{array}$ & Ratio \\
\hline
\end{tabular}

Measurement techniques used to calculate the independent variables are based on previous studies (Craig and Diga 1998; Haniffa and Cooke 2000; Nurhayati et al. 2006; Cahaya et al. 2008).

The industry sensitivity (SEN) variable is measured by classifying nine industry sectors of the samples into two groups in accordance to their impacts of their business operation on the environment (Nurhayati et al. 2006). The first group is assigned a SEN value of 0 (environmentally insensitive industry sector) and is comprised of samples from Property, Real Estate and Building Construction; Infrastructure; Utilities and Transportation; Finance and Trade, Services and
Investment industry sectors. Accordingly, samples from Agriculture; Mining; Basic Industry and Chemicals; Miscellaneous Industry and Consumer Goods Industry sectors are designated with a SEN value of 1 (environmentally sensitive industry sector). Table summarizes the measurement procedures for independent variables used in this research.

The following multiple linear regression equation applies a panel data fixed effect estimation model:

$$
\begin{aligned}
\mathrm{EDI}_{\mathrm{it}}= & \alpha_{0}+\alpha_{1} \mathrm{LAST}_{\mathrm{it}}+\alpha_{2} \mathrm{LEV}_{\mathrm{it}}+\alpha_{4} \mathrm{SUB}_{\mathrm{it}} \\
& +\alpha_{5} \mathrm{INT}_{\mathrm{it}}+\alpha_{6} \mathrm{SEN}_{\mathrm{it}}+\alpha_{7} \mathrm{SHM}_{\mathrm{it}} \\
& +\alpha_{8} \mathrm{KOM}_{\mathrm{it}}+\mathrm{u}_{\mathrm{it}}
\end{aligned}
$$




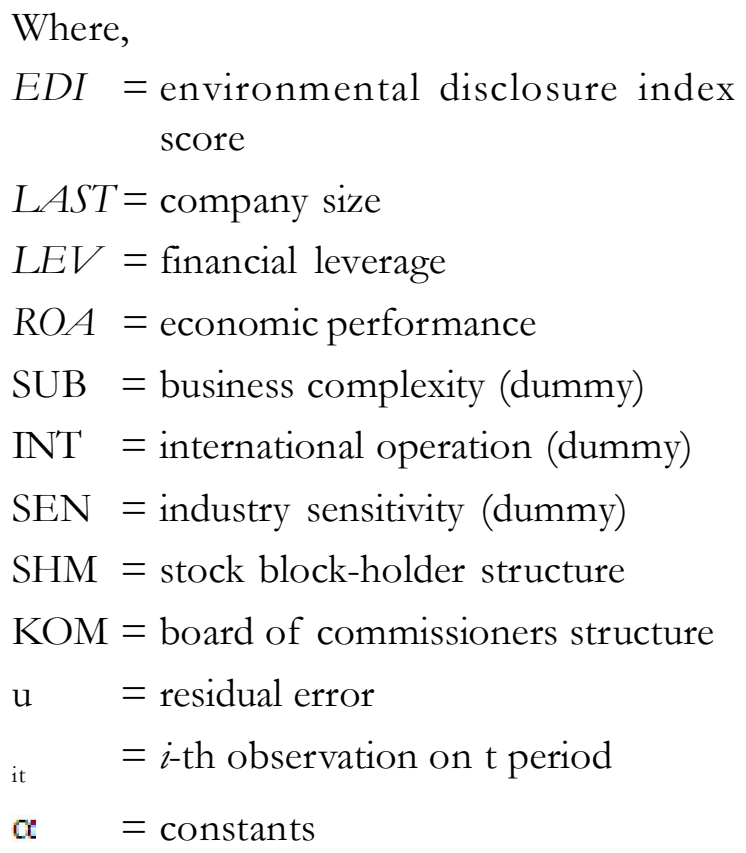

\section{Results}

From the total of 316 companies registered in the Indonesia Stock Exchange for the year 2008 (IDX 2008), 35 companies are obtained as samples for each period of observation (see Appendix 3). Consequently, the total number of observations for this research is 140 firm-years. The summary of descriptive statistics results for independent variables used in this research is depicted in Table 2 and Table 3 respectively.

From the descriptive statistics results, the mean value of 58.19 percent for LEV indicates that the majority of sampled companies are highly leveraged. This high value is caused by the inclusion of financial insti-

Table 2. Descriptive Statistics Summary of Non-Dummy Independent Variables

\begin{tabular}{llcccc}
\hline No. & $\begin{array}{l}\text { Non-Dummy } \\
\text { Variable }\end{array}$ & Minimum & Maximum & Mean & Std. Deviation \\
\hline 1 & $\begin{array}{l}\text { Total Assets } \\
\text { (in billion IDR) }\end{array}$ & 118 & 358,439 & 27,255 & 60,290 \\
2 & LEV & 0.1706 & 0.9807 & 0.5819 & 0.2111 \\
3 & ROA & -0.1972 & 0.6216 & 0.0627 & 0.0937 \\
4 & SHM & 0.13 .08 & 0.9900 & 0.5085 & 0.2013 \\
5 & KOM & 0.1667 & 0.8000 & 0.4243 & 0.1179 \\
\hline
\end{tabular}

Table 3. Descriptive Statistics Summary of Dummy Independent Variables

\begin{tabular}{|c|c|c|c|}
\hline No & Dummy Variable & Observed Frequency & Percentage \\
\hline 1 & $\begin{aligned} \text { SUB: } & \text { - No subsidiary } \\
& \text { - Subsidiary exist }\end{aligned}$ & $\begin{array}{r}18 \\
122\end{array}$ & $\begin{array}{l}12.86 \\
87.14\end{array}$ \\
\hline 2 & $\begin{aligned} \text { INT: } & \text { - No international operation } \\
& \text { - International operation }\end{aligned}$ & $\begin{array}{l}59 \\
81\end{array}$ & $\begin{array}{l}42.14 \\
57.86\end{array}$ \\
\hline 3 & $\begin{aligned} \text { SEN: } & \text { - Environmentally insentive } \\
& \text { - Environmentally sensitive }\end{aligned}$ & $\begin{array}{l}80 \\
60\end{array}$ & $\begin{array}{l}57.14 \\
42.86\end{array}$ \\
\hline
\end{tabular}


tutions (banks) as sampled in this research, which is characterized by their high levels of leverage. Furthermore, it can be inferred that the mean value of 50.85 percent for SHM variable suggests that the ownership of public companies in Indonesia is still dominated by a single majority stakeholder.

The result of the above table for SUB variable suggests that the majority $(87.14 \%)$ of sampled public companies had at least one subsidiary. Meanwhile, more than half of the companies $(57.86 \%)$ engaged in international business operations. In addition, 57.14 percent of the sampled companies operated in business with no direct impact to environment.

The results of the dependent variable (EDI/Environmental Disclosure Index) mean value ranked by industry sectors are illustrated at the Table 4.

Indonesian public companies operating in the mining sector exhibit the highest level of environmental disclosure, with a mean value of 0.6538 . The second and third industries with a high EDI mean value are miscellaneous and consumer goods industries with an EDI mean value of 0.3462 and 0.2788 respectively. It should be noted that the difference of EDI mean value between the first and second rank is significant $(88.9 \%)$. This result indicates a significant difference of environmental disclosure level for samples across different industries.

In order to ensure that the panel data equation estimation results faithfully represent the tested samples; assumption tests such as normality, multicollinearity, and heterocedasticity tests have been done and satisfied before conducting the multiple linear regression. The estimation results of multiple liner regression for the hypotheses which apply the panel data fixed effect estimation model are exhibited in Table 5.

Table 4. Dependent Variable Mean Value Ranking based on Industry Sector

\begin{tabular}{clc}
\hline Rank & \multicolumn{1}{c}{ Industry Sector } & EDI Mean Value \\
\hline I & Mining & 0.6538 \\
II & Miscellaneous Industry & 0.3462 \\
III & Consumer Goods Industry & 0.2788 \\
IV & Infrastructure, Utility, and Transportation & 0.2222 \\
V & Basic and Chemical Industry & 0.1795 \\
VI & Agriculture & 0.1731 \\
VII & Property, Real Estate, and Building Construction & 0.1722 \\
VIII & Finance & 0.1296 \\
IX & Trade, Service, and Investment & 0.1019 \\
\hline
\end{tabular}


Table 5. Multiple Linear Regression Estimation Result with Panel Data Fixed Effect Model

\begin{tabular}{lcccc}
\hline \multicolumn{1}{c}{ Variable } & Coefficient & Standard Error & t-Statistics & p-value \\
\hline$\alpha$ & -0.172 & 0.113 & -1.513 & 0.133 \\
Company size & 0.034 & 0.008 & 4.376 & $0.000^{* * *}$ \\
Financial leverage & -0.283 & 0.061 & -4.630 & $0.000^{* * *}$ \\
Economic performance & 0.525 & 0.137 & 3.832 & $0.000^{* * *}$ \\
Business complexity & -0.089 & 0.036 & -2.508 & $0.013 * *$ \\
Extent of international operation & -0.019 & 0.034 & -0.555 & 0.580 \\
Industry sensitivity & 0.093 & 0.035 & 2.637 & $0.009 * * *$ \\
Stock block-holder structure & -0.121 & 0.058 & -2.075 & $0.040 * *$ \\
Board of Commissioners' structure & 0.198 & 0.110 & 1.792 & $0.076 *$ \\
R-squared & 0.543567 & & & \\
Adjusted R-squared & 0.504342 & & & \\
\hline
\end{tabular}

$* * *$ Significant at $\alpha=1$ percent (two-tailed probability)

** Significant at $\alpha=5$ percent (two-tailed probability)

* Significant at $\alpha=10$ percent (two-tailed probability)

\section{Discussion and Conclusion}

The internal characteristics of observed Indonesian public companies are categorized into three dimensions, namely financial, nonfinancial and corporate governance attributes. Financial attributes are represented by company size, financial leverage, and economic performance (profitability). The company size has a linear relationship with the extent of voluntary GRI based environmental disclosure of Indonesian public companies. Larger companies are more vulnerable to high political cost (Watts and Zimmerman 1978), which in turn compels them to provide greater voluntarily disclosure to the public in order to evade excessive oversight and regulations from the public and government. This conclusion is consistent with previous research performed by Spicer (1978), Cooke (1989), Meek et al. (1995), Brammer and Pavelin (2004), Nurhayati et al. (2006), Cahaya et al. (2008), and Gurdip and Joshi (2009).

Economic performance has in-line relationship with the extent of voluntary GRI based environmental disclosure of Indonesian public companies. Singhvi and Desai (1971) argue that if the company has better rate of return (profitability), the management will have more incentives to disclose more complete information in order to support the sustainability of their station and compensation. This result corresponds with the findings obtained in Singhvi and Desai (1971) and Roberts (1992) research.

The estimation result for financial leverage shows an inverse relationship with the 
extent of environmental disclosure; which is consistent with the proposed hypothesis. This result can be interpreted as the indifference of creditors of public companies in Indonesia in responding of the additional environmental information disclosed by the management. This conclusion corresponds with the result obtained by Meek et al. (1995).

Non-financial attributes are represented by business complexity, the extent of international operation, and industry sensitivity. The industry sensitivity has a positive relationship with the extent of voluntary GRI based environmental disclosure of Indonesian publicly listed companies, in which companies operating in more ecologically sensitive industry sectors tend to disclose more environmentally related information. This is consistent with the findings obtained by Craig and Diga (1998), Nurhayati et al. (2006), and Gurdip and Joshi (2009).

Inverse relationships exist between business complexity and the extent of environmental disclosure. One line of reasoning for such finding is that there is a tendency for Indonesian publicly listed companies that operate the business through their subsidiaries to conceal information through the use of aggregation/ consolidation of annual reports.

In addition, this research cannot identify the association between the extent of international operation and the extent of environmental disclosure. This lack of relationship is caused by a minor contribution of the international operation (sales) for Indonesian public companies compared to the overall business operation. As a result, there is a lack of incentives for the management to provide additional and better quality disclosure information for foreign stakeholders. This finding is consistent with the result obtained by Meek et al. (1995) and Craig and Diga (1998).
Corporate governance attributes are represented by the stock block-holder structure and the Board of Commissioners' structure. An inverse relationship exists between the stock block-holder structure and the extent of voluntary GRI based environmental disclosure. This finding reveals that a more centralized ownership of stock by institutional ownership will negatively impact the amount of disclosed information. The already low equity cost of agency, which is expected in entity with highly centralized stock ownership (McKinnon and Dalimunthe 1993), will discourage the motivation of management to provide additional non-financial disclosure to the public.

The moderate association which exists between the proportions of independent commissioners with the degree of disclosed environmental information. This finding is consistent with the studies of Chen and Jaggi (2000) and Haniffa and Cooke (2000). This result is caused by the Bapepam (Capital Market Supervisory Agency) Regulation No. SE-03/PM/2000 and the Indonesia Stock Exchange Regulation No. I-A, which mandated that a minimum of 30 percent of the board of commissioners' members to be independent. In addition, this research includes samples from publicly listed banks, which are subjected to Bank of Indonesia Regulation No. 8/4/PBI/2006. The law mandated that a minimum 50 percent of the members of the Board of Commissioners must be independent. Thus, the weak relationship between the proportion of independent commissioners and the extent of environmental disclosure in this research is significantly influenced by the legal regulations on corporate governance in Indonesian jurisdiction.

This research has several limitations to consider. Firstly, the paper's observation pe- 
riod only covers five years (2005-2008), as environmental information were not commonly disclosed in Indonesian public companies annual reports prior to 2005. Secondly, this research only includes published environmental information in annual reports and accompanying supplemental reports. Alternative information channels used by companies to inform environmental information to stakeholders such as web pages and social networks are not covered in this paper.

For future research, there are two points for further consideration. Firstly, the inclusion of the composition of the independent board of commissioners as an explanatory variable in future research which covers different industries and jurisdictions should be carefully considered, since certain corporate governance legal statutes require public companies to maintain a certain number of independent commissioners. Secondly, considering the wide disparity of EDI mean value across industries as presented in Table 4, future research could choose to focus on the unique characteristics of certain industries which influence the disclosure of environmental information.

This paper concluded that certain characteristics of public companies in Indonesia highly influence the extent of environmental information disclosed. Investors in capital markets are increasingly aware on the importance of sustainable development and will accordingly reward public companies who actively disclose environmental information (Cohen and Fenn 1997). By taking the results of this research into consideration, Indonesian Capital Market Supervisory Agency and stock market authority may consider to mandate a certain degree of obligatory environmental information disclosure to public companies which satisfies specific requirements. This effort will further enhance the capital market information transparency and fulfill investors' demands of availability of relevant information for the purpose of making longterm investment decisions.

\section{References}

Brammer, S., and S. Pavelin. 2004. Voluntary social disclosures by large UK companies. Business Ethics: $A$ European Review 13 (July): 86-99.

Cahaya, F. R., S. A. Porter, and A. M. Brown. 2008. Social disclosure practices by Jakarta Stock Exchange listed entities. Journal of the Asia-Pacific Centre for Environmental Accountability 14 (1): 2-11.

Chen, C. J., and B, Jaggi. 2000. Association between independent non-executive directors, family control and financial disclosures in Hong Kong. Journal of Accounting and Public Policy 19 (4/5): 285-310.

Cohen, M. A., S. A. Fenn, and S. Konar. 1997. Environmental and Financial Performance: Are They Related?: 140.

Cooke, T. E. 1989. Disclosure in the corporate annual reports of Swedish companies. Accounting and Business Research 19 (74): 113-124.

Cornell, B., and A. C. Shapiro. 1987. Corporate stakeholders and corporate finance. Financial Management (Spring): 5-14.

Craig, R., and J. Diga. 1998. Corporate accounting disclosure in ASEAN. Journal of International Financial Management \& Accounting 9 (3): 246-274. 
Foster, G., 1986. Financial Statement Analysis. Englewood Cliffs, N. J.: Prentice-Hall.

Gray R., D. Owen, and C. Adams. 1996. Accounting and Accountability. Englewood Cliffs, NJ: Prentice-Hall. Global Reporting Initiative (GRI). 2009. Year in review. Annual Report.

Gujarati, D. N., and D. C. Porter. 2009. Basic Econometrics (5 ${ }^{\text {th }}$ ed.). Singapore: McGraw-Hill.

Gurdip, S., and M. Joshi. 2009. Environment management and disclosure practices of Indian companies. International Journal of Business Research 9 (2): 116-128.

Haniffa, R., and T. Cooke. 2000. Culture, Corporate Governance and Disclosure in Malaysian Corporations. Singapore: Asian AAA World Conference.

Ijiri, Y. 1983. On the accountability-based conceptual framework of accounting. Journal of Accounting and Public Policy: $75-81$.

Indonesia Stock Exchange (IDX). 2008. IDX Fact Book 2008. Research and Product Development Division.

KPMG. 2008. KPMG International Survey of Corporate Responsibility Reporting 2008.

McKinnon, J. L., and L. Dalimunthe. 1993. Voluntary disclosure of segment information by australian diversified companies. Accounting and Finance 33 (1): 33-50.

Meek, G. K., C. B. Roberts, and S. J. Gray. 1995. Factors influencing voluntary annual report disclosures by U.S., U.K. and Continental European multinational corporations. Journal of International Business Studies 26 (3): 555-572.

Nurhayati, R., A. Brown, A. and G. Tower. 2006. A Developing Country's Natural Environment Disclosure Index. Wellington, New Zealand: AFAANZ Conference.

Roberts, R. W. 1992. Determinants of corporate social responsibility disclosure: An application of stakeholder theory. Accounting, Organizations and Society 17 (6): 595-612.

Schadewitz, H. J., and D. R. Blevins. 1998. Major determinants of interim disclosures in an emerging market. American Business Review 16 (11): 41-55.

Shane, P. B., and B. H. Spicer. 1983. Market response to environmental information produced outside the firm. The Accounting Review LVIII (3): 521-538.

Singhvi, S. S., and H. B. Desai. 1971. An empirical analysis of the quality of corporate financial disclosure. The Accounting Review 46 (1): 129-138.

Spicer, B. H. 1978. Investors, corporate social performance and information disclosure: An empirical study. The Accounting Review LIII (1): 94-111.

Watts, R. L., and J. L. Zimmerman. 1978. Towards a positive theory of the determination of accounting standards. The Accounting Review LIII (1): 112-134.

Watts, R. L., and J. L. Zimmerman. 1990. Positive accounting theory: A ten year perspective. The Accounting Review 65 (1): 131-156.

Zarzeski, M. T. 1996. Spontaneous harmonization effects of culture and market forces on accounting disclosure practices. Accounting Horizons 10 (1): 18-37. 


\section{Appendices}

\section{Appendix 1. Disclosure Indicators for Environmentally Insensitive Industry Sector $(\mathrm{SEN}=0)$}

No.

Disclosure Indicators

1 Initiatives for saving resources consumption (recycling).

2 Amount of energy consumption

3 Initiatives to provide energy-efficient, renewable energy-based or environmentally friendly products or services.

4 Strategies or descriptions of waste/emission processing.

5 Initiatives to reduce energy consumption and reductions in energy requirements as a result of these initiatives.

6 Strategies, current actions and future plans for managing company's operation impacts on biodiversity.

7 Initiatives to reduce air emissions or greenhouse gas.

8 Initiatives to improve quality of environment.

9 Descriptions of violation of environmental laws and regulations.

Appendix 2. Disclosure Indicators for Environmentally Sensitive Industry Sector $(\mathrm{SEN}=1)$

No. Disclosure Indicators

1 Descriptions of materials used in company's operation.

2 Descriptions of recycled or reprocessed materials used in company's operation.

3 Amount of energy consumption

4 Reductions in energy requirements as a result of conservation initiatives.

5 Initiatives to provide energy-efficient, renewable energy-based or environmentally friendly products or services.

6 Initiatives to reduce energy consumption.

$7 \quad$ Conservation and recycling efforts to process effluent.

8 Strategies, current actions and future plans for managing company's operation impacts on biodiversity.

9 Initiatives to reduce air emissions or greenhouse gas.

10 Descriptions of air emissions resulting from company's operation.

11 Strategies or descriptions of solid waste processing.

12 Initiatives to minimize impacts of company's operation on environment.

13 Descriptions of violation of environmental laws and regulations. 
Appendix 3. List of Samples

\begin{tabular}{ccc}
\hline No. $\begin{array}{l}\text { Stock } \\
\text { Code }\end{array}$ & Name of Company & $\begin{array}{c}\text { Industry Sector } \\
\text { Classification }\end{array}$ \\
\hline
\end{tabular}

\begin{tabular}{|c|c|c|c|}
\hline 1 & UNSP & PT Bakrie Sumatra Plantations Tbk. & Agriculture \\
\hline 2 & MBAI & PT Multibreeder Adirama Indonesia Tbk. & \\
\hline 3 & INCO & PT International Nickel Indonesia Tbk. & Mining \\
\hline 4 & SOBI & PT Sorini Agro Asia Corporindo (Sorbitol) Tbk. & Basic Industry and Chemicals \\
\hline 5 & AMFG & PT Asahimas Flat Glass Tbk. & \\
\hline 6 & JPFA & PT Japfa Comfeed Indonesia Tbk & \\
\hline 7 & BRPT & PT Barito Pacific Timber Tbk. & \\
\hline 8 & INTP & PT Indocement Tunggal Prakarsa Tbk. & \\
\hline 9 & UNIC & PT Unggul Indah Cahaya Tbk. & \\
\hline 10 & GJTL & PT Gajah Tunggal Tbk. & Miscellaneous Industry \\
\hline 11 & ASII & PT Astra International Tbk. & \\
\hline 12 & SMAR & PT Sinar Mas Agro Resources and Technology Tbk. & Consumer Goods Industry \\
\hline 13 & RMBA & PT Bentoel International Investama Tbk. & \\
\hline 14 & KAEF & PT Kimia Farma (Persero) Tbk. & \\
\hline 15 & UNVR & PT Unilever Indonesia Tbk. & \\
\hline 16 & LPKR & PT Lippo Karawaci Tbk. & Property, Real Estate and Building Construction \\
\hline 17 & CTRA & PT Ciputra Development Tbk. & \\
\hline 18 & JIHD & PT Jakarta International Hotel Tbk. & \\
\hline 19 & GMTD & PT Gowa Makassar Tourism Development Tbk. & \\
\hline 20 & ADHI & PT Adhi Karya (Persero) Tbk. & \\
\hline 21 & PGAS & PT Perusahaan Gas Negara (Persero) Tbk. & Infrastructure, Utilities and Transportation \\
\hline 22 & CMNP & PT Citra Marga Nusaphala Persada Tbk. & \\
\hline 23 & TLKM & PT Telekomunikasi Indonesia (Persero) Tbk. & \\
\hline 24 & BDMN & PT Bank Danamon Tbk. & Finance \\
\hline 25 & BNLI & PT Bank Permata Tbk. & \\
\hline 26 & PNBN & PT Pan Indonesia (Panin) Bank Tbk. & \\
\hline 27 & BBRI & PT Bank Rakyat Indonesia (Persero) Tbk. & \\
\hline 28 & BBIA & PT Bank UOB Buana Tbk. & \\
\hline 29 & BMRI & PT Bank Mandiri (Persero) Tbk. & \\
\hline 30 & MAPI & PT Mitra Adiperkasa Tbk. & Trade, Services and Investment \\
\hline 31 & HERO & PT Hero Supermarket Tbk. & \\
\hline 32 & TMPO & PT Tempo Inti Media Tbk. & \\
\hline 33 & PJAA & PT Pembangunan Jaya Ancol Tbk. & \\
\hline 34 & JSPT & PTJakarta Setiabudi Property Tbk. & \\
\hline 35 & EPMT & PTEnseval Putera Megatrading Tbk. & \\
\hline
\end{tabular}

